\title{
Behavior and Viability of Blueberry Seeds through Germination and Tetrazolium Test
}

\author{
Ana Paula de Azevedo Pasqualini' ${ }^{1}$, Jessé Neves dos Santos ${ }^{2}$, Ricardo Antonio Ayub ${ }^{3 *}$ \\ ${ }^{1}$ Paraná Federal University, Curitiba, Brazil \\ ${ }^{2}$ Ponta Grossa State University, Ponta Grossa, Brazil \\ ${ }^{3}$ Phytotchny and Phytosanitary Department, Ponta Grossa State University, Ponta Grossa, Brazil \\ Email: anapauladeazevedo@gmail.com, jessens2@hotmail.com, rrayub@uepg.br
}

Received 20 October 2015; accepted 19 January 2016; published 25 January 2016

Copyright (C) 2016 by authors and Scientific Research Publishing Inc.

This work is licensed under the Creative Commons Attribution International License (CC BY).

http://creativecommons.org/licenses/by/4.0/

c) (i) Open Access

\begin{abstract}
Knowing the physiology of seeds and the elements that influence their germination is fundamental aspects in seminiferous propagation; important techniques are used to obtain genetic variability and development of new cultivars of blueberry. The aim of this study is to evaluate the germination behavior, as well as viability levels, through germination tests and tetrazolium, of Vaccinium ashei Reade seed cultivars Briteblue and Climax. Seeds treated or not with $5 \mathrm{M}$ potassium hydroxide $(\mathrm{KOH})$ were submitted to the germination test, on substrates, filter paper (SP) or solid culture medium with half of the salt concentration (MS/2), at temperatures of $10^{\circ} \mathrm{C} \pm 2^{\circ} \mathrm{C}$ or $25^{\circ} \mathrm{C} \pm 2^{\circ} \mathrm{C}$. The maximum germination percentage of blueberry seeds was $40 \%$. Both temperatures and substrates caused seed germination in the tested cultivars, and pretreatment with $5 \mathrm{M} \mathrm{KOH}$ for 5 minutes inhibited germination. Yet, the tetrazolium test, based on coloration of tissue, allowed the establishment of different levels of viability.
\end{abstract}

\section{Keywords}

Vaccinium ashei Reade, Germination Behavior, Dormancy

\section{Introduction}

Brazil has produced 59 t blueberry in 2012, in an area of 270 planted hectares in South and Southeast regions [1], and the most promising specie for regions of cold weather is the Vaccinium ashei; the species' cultivars that are better adapted to the Brazilian weather conditions are: Aliceblue, Bluebelle, Bluegem, Briteblue, Climax, Delite,

${ }^{*}$ Corresponding author.

How to cite this paper: de Azevedo Pasqualini, A.P., dos Santos, J.N. and Ayub, R.A. (2016) Behavior and Viability of Blueberry Seeds through Germination and Tetrazolium Test. Advances in Bioscience and Biotechnology, 7, 11-18.

http://dx.doi.org/10.4236/abb.2016.71002 
Powderblue, Woodhard [2]. These cultivars are selected from other countries with different edaphoclimatic conditions displaying limitations for its cultivation, which drives the need for superior plants that are able to adapt to Brazil's particularities [3]. When searching for genetic variability and the development of new cultivars, the propagation of blueberry seeds becomes important [2].

In order to achieve satisfactory results in seminiferous propagation, it is imperative to know the seed's germinative behavior and physiologic quality, which can be evaluated through germination and force test, such as the tetrazolium test [4].

Seed's germination constitutes of a sequence of physical, biochemical and physiologic events, influenced by a variety of factors, which can act isolated or combined [5]. Those factors can be extrinsic, such as: light, temperature and humidity; and intrinsic, like: morphology, viability and dormancy [6].

As far as extrinsic factors are concerned, the Vaccinium seeds have its germination affected by temperature [7] and present positive and orthodox photoblastic behavior [8], meaning it germinates in the presence of light, and is able to maintain the viability even with low humidity content [9].

In a germination test, the substrate is another extern factor that influences seeds germination, due to its structure, aeration, water retention capacity and level of pathogens infestation [10]. The paper filter is the most utilized support in seeds germination, due to its capacity to simplify the test, increase the speed, and reduce costs [11]. However, the usage of MS medium culture [12] was cited as a substrate for seeds germination of Vaccinium meridionale Swartz since reduction of salts concentration in the culture medium allowed greater percentage of germination [13].

At the end of a germination test, the presence of non-germinated seeds may occur, because those died, were hard or in dormancy [14]. The seeds dormancy can be classified in: physiological, morphological, physical and combined (physical and physiological) dormancy [15]. The impermeability of the seed coat is a physical dormancy, which prevents the entry of water [16] and can be caused by the presence of substances such as suberin, lignin, cutin, tannins, pectins, as well as derivates of quinine [17]. Chemical studies indicate that the cuticle and pigment chains, present in the seed coat, are composed by insoluble polymeric materials, which can be depolymerized by alkaline hydrolysis [18] with $\mathrm{KOH}$ or $\mathrm{NaOH}$ [19].

Viable seeds that are considered in dormancy, present a temporary blockage to complete the germination [20]. The tetrazolium test is a fast method to determinate the viability of the seeds, based on the activity of dehydrogenase enzymes, present in living tissues [21].

The aim of the present work was to determinate the germinative behavior and levels of the viability of the seeds of Vaccinium ashei Reade cultivars Briteblue and Climax, by germination and tetrazolium tests.

\section{Material and Methods}

\section{Site and biologic material}

Blueberry seedlings from cvs. Climax and Briteblue experimentally planted in spacing of $4.0 \mathrm{~m} \times 1.5 \mathrm{~m}$ in 2010, in Ponta Grossa-PR (2505'35"S e 5003'50"W e $950 \mathrm{~m}$ de altitude). The weather is classified as cfb [22], presenting well-defined dry seasons, frequent frosts during winter and soil Haplic cambisol dystrophic of clay texture, produced the fruits used in the experiments.

Experiment 1-Physiological quality and germinative behavior of Vaccinium ashei Reade seeds, cultivars Briteblue and Climax, treated or not with $5 \mathrm{M}$ of potassium hydroxide (KOH), and submitted to the germination test in different substrates and temperatures

Ripe fruits, collected in February of 2012, were taken to the laboratory, selected, macerated and depulped in order to obtain the seeds. The seeds were washed with running water, spread on paper towels and shade dried at room temperature for 24 hours. Two experiments were performed, one using cv. Briteblue seeds, placed in the refrigerator for two months, and the other with fresh cv. Climax seeds. Furthermore, both cultivars' seeds were soaked in $\mathrm{H}_{2} \mathrm{O}$ (control) or potassium hydroxide solution $5 \mathrm{M}(\mathrm{KOH})$ for 5 minutes, and then submitted to the germination test, installed in Petri dishes, containing the autoclaved substrates: filter paper (SP) periodically moistened with sterile distilled water (2.5 times the weight of the substrate in water) or solid culture medium MS (6 $\mathrm{g} \cdot \mathrm{L}^{-1}$ of agar) with half of salt concentrations $(\mathrm{MS} / 2)$. Then, the dishes were vetoed with plastic wrap and kept at constant temperatures of $10^{\circ} \mathrm{C} \pm 2^{\circ} \mathrm{C}$ (BOD like cabinet) or $25^{\circ} \mathrm{C} \pm 2^{\circ} \mathrm{C}$ (climatized room with air conditioning), with photoperiod of 16 hours of light, making the following treatments: $\mathrm{T} 1$ ) Control $+\mathrm{SP}+10^{\circ} \mathrm{C}, \mathrm{T} 2$ ) Control $+\mathrm{SP}+25^{\circ} \mathrm{C}$, T3) Control $+\mathrm{MS} / 2+10^{\circ} \mathrm{C}$, T4) Control $\left.\left.+\mathrm{MS} / 2+25^{\circ} \mathrm{C}, \mathrm{T} 5\right) \mathrm{KOH}+\mathrm{SP}+10^{\circ} \mathrm{C}, \mathrm{T} 6\right)$ 
$\mathrm{KOH}+\mathrm{SP}+25^{\circ} \mathrm{C}$, T7) $\left.\mathrm{KOH}+\mathrm{MS} / 2+10^{\circ} \mathrm{C}, \mathrm{T} 8\right) \mathrm{KOH}+\mathrm{MS} / 2+25^{\circ} \mathrm{C}$. The experimental design was completely randomized with eight treatments, four replicates, and the experimental unit consisted of a Petri dish, containing 10 seeds. The effect of the use of $\mathrm{KOH}$, substrates and temperatures on the germination performance of the seeds was evaluated by the percentage of germination and the first count of normal seedlings (presented all of the essential structures developed). After obtaining the first normal seedling, successive counts were performed every 7 days. The test finished when there was absence of germination after 30 days of test. The percentage data of germination were transformed to arcsen $\sqrt{ } \mathrm{P} \% / 100$, submitted to the Barlett test, followed by analysis of variance, and when significant were compared by Duncan test $(\mathrm{p} \leq 0.05)$, using the SAS statistical package.

Experiment 2-Levels of seeds viability of Vaccinium ashei Reade cultivars Briteblue and Climax through the tetrazolium test

Fruits from cultivars Briteblue and Climax were collected in January of 2013, and were taken to the laboratory and placed under refrigaration. To separate the pulp from the seeds, fruits were placed together with water in a mixer. Next, the seeds were washed with running water, spread on paper towels and shade dried at room temperature for 3 days. To perform the tetrazolium test, three repetitions of 50 seeds were used; 150 seeds in total were pre-wetted by immersion in water for 24 hours, and the exposure of the fabrics to staining were made by a needle in the opposite side of the location of the embryo. Then, the seeds were immersed in a colorless solution of 2,3,4-triphenyl tetrazolium bromide $1 \%$ for 3 hours at $30^{\circ} \mathrm{C}$ and then kept 21 hours at room temperature in complete darkness condition [8]. After being immersed, the seeds were washed with running water and transversely cut with razor to visualize the embryo [14] in optic microscope (50× increase). The viability was scored by percentage of embryo color ( $0,25,50,75$ and $100 \%)$, and stained seeds with embryo above $50 \%$ were considered viable.

\section{Results and Discussion}

Experiment 1-Physiological quality and germinative behavior of Vaccinium ashei Reade seeds, cultivars Briteblue and Climax, treated or not with $5 \mathrm{M}$ of potassium hydroxide (KOH), and submitted to the germination test in different substrates and temperatures

The disposal of the treatments T3 and T4 (Briteblue cultivar), and T2, T5 and T6 (Climax cultivar) was due to a contamination of the substrate by fungus. This interfered de evaluation of the factors: exposition or not to potassium hydroxide $(\mathrm{KOH})$, substrates $(\mathrm{SP}$ and $\mathrm{MS} / 2)$ and temperatures $\left(10^{\circ} \mathrm{C}\right.$ and $\left.25^{\circ} \mathrm{C}\right)$ in factorial arrangement $2 \times 2 \times 2$.

Table 1 shows the results of analysis of variance of germination percentage transformed to arcsin $\sqrt{ } \mathrm{P} \% / 100$, and the value of chi-square $\left(\chi^{2}\right)$ for the Barlett test, which showed homogeneity of variances of treatments.

For the germination test of blueberry seeds of Briteblue cultivar, in the treatments $\mathrm{T} 1$ and T2, which contained seeds immersed in water for 5 minutes and germinated on paper, had germination percentages of $30 \%$ and $40 \%$ respectively, yet they did not differ significantly as a function of temperature $\left(10^{\circ} \mathrm{C}\right.$ and $\left.25^{\circ} \mathrm{C}\right)$. To the $\mathrm{T} 6$ and $\mathrm{T} 8$

Table 1. Test results of variance of germination percentage of data of the seeds of Vaccinium ashei Reade, Briteblue and Climax cultivars.

\begin{tabular}{|c|c|c|}
\hline \multicolumn{3}{|c|}{ Vaccinium ashei Reade Briteblue Cultivar } \\
\hline Variation Sources & G.L. & Mean Square \\
\hline Treatments & 5 & $0.00131635^{*}$ \\
\hline Error & 18 & 0.00037102 \\
\hline Chi-Square $\left(\chi^{2}\right)$ & & $8.42603^{*}$ \\
\hline \multicolumn{3}{|c|}{ Vaccinium ashei Reade Climax Cultivar } \\
\hline Variation Sources & G.L. & Mean Square \\
\hline Treatments & 4 & $0.00164518^{*}$ \\
\hline Error & 15 & 0.00015064 \\
\hline Chi-Square $\left(\chi^{2}\right)$ & & $7.08139^{*}$ \\
\hline
\end{tabular}

\footnotetext{
* significant at $5 \%$ of probability.
} 
treatments, which contained seeds, treated with $5 \mathrm{M}$ of $\mathrm{KOH}$ and were germinated at a temperature of $25^{\circ} \mathrm{C}$, had germination percentages of $7 \%$ and $10 \%$ respectively; these did not differ significantly in relation with the substrate (SP and MS/2).

The T2 treatment revealed to be statistically superior to the T6 treatment, showing that the exposure of the seeds to $5 \mathrm{~m}$ of $\mathrm{KOH}$ inhibited the germination in relation with the seeds that were only immersed in water and germinated on paper at the same temperature (Figure 1).

For the Climax cultivar, the T1 and T4 treatments, presented the best statistical performance and germination percentages of $40 \%$ and $30 \%$ respectively, surpassing the other treatments. The T7 treatment, which had seeds treated with $5 \mathrm{M}$ of $\mathrm{KOH}$ and was germinated on the substrate $\mathrm{MS} / 2$ at $25^{\circ} \mathrm{C}$, presented inferior statistical results than the other treatments, and germination percentage of $5 \%$ (Figure 2).

The first detached normal seedling was obtained after 46 days to Climax cv. treatment $\mathrm{T} 8(\mathrm{KOH}+\mathrm{MS} / 2+$ $\left.25^{\circ} \mathrm{C}\right)$ and after 52 days to Briteblue cv. on treatment $\mathrm{T} 5\left(\mathrm{KOH}+\mathrm{SP}+10^{\circ} \mathrm{C}\right)$. Seeds of Vaccinium meridionale Swartz, stored for a week in ambient conditions at a temperature of $18^{\circ} \mathrm{C} \pm 2^{\circ} \mathrm{C}$, using as substrate the culture medium MS with 1/3,1/8 and 1/16 of the salt concentration, initiated the germination 42 days post the test installation [13].

The germination test of the seeds of Vaccinium ashei Reade Briteblue and Climax cultivars was terminated after 6 months of its installation, when the absence of germination was superior to 30 days. Evidence of dor-

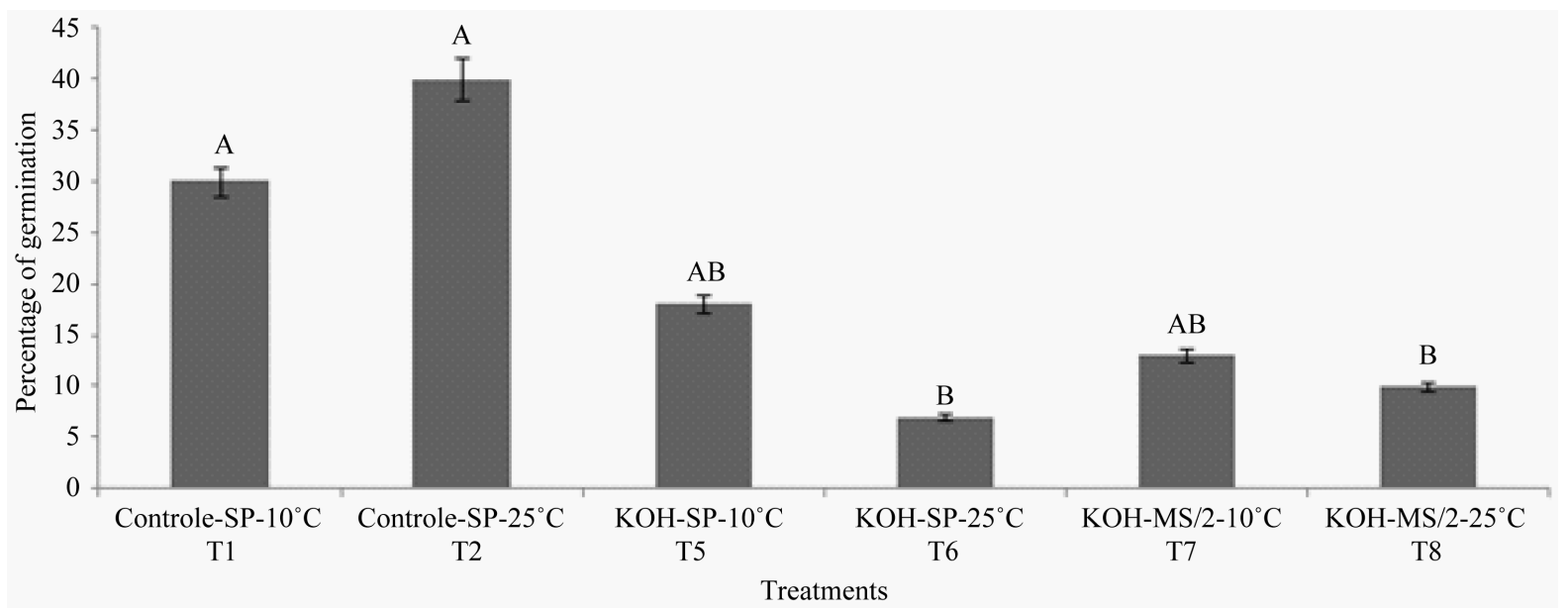

Figure 1. Germination of the blueberry seeds Briteblue cv. in different germinative treatments. Ponta Grossa, PR, 2012. *By the Duncan test $\mathrm{p}<0.05$, means followed by the same letter do not differ among themselves.

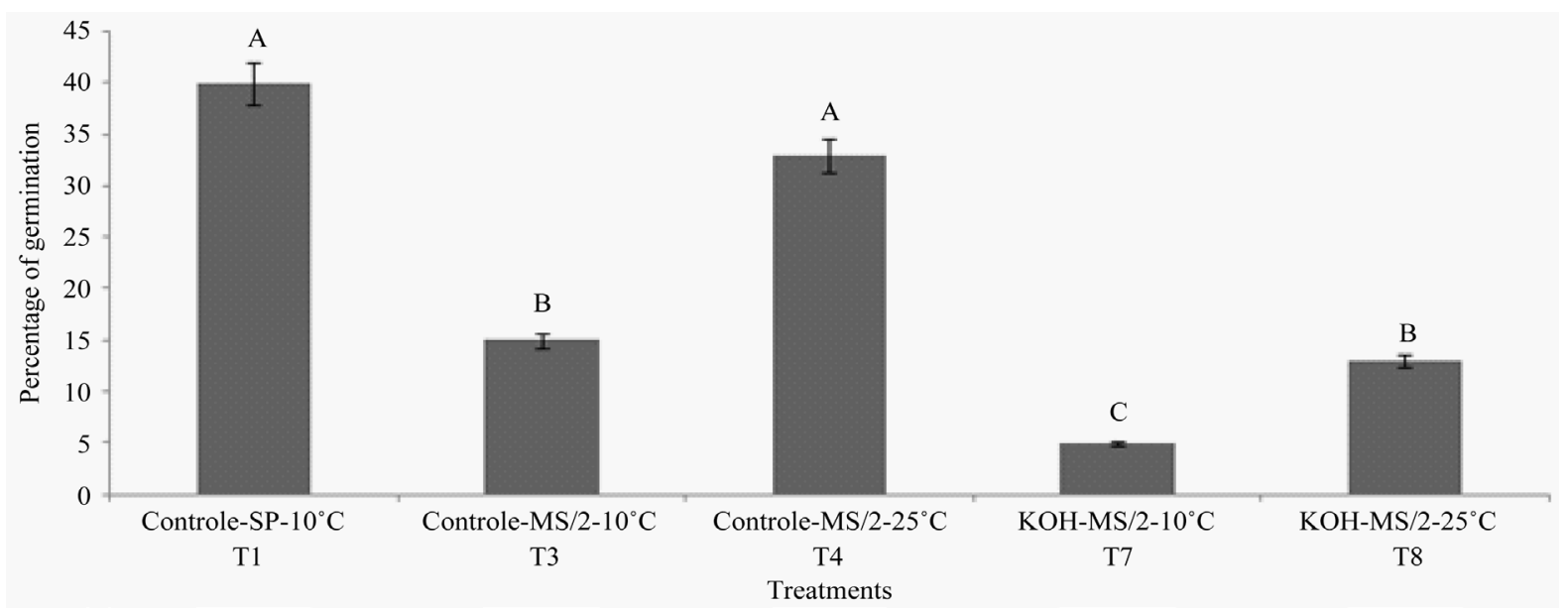

Figure 2. Germination of the blueberry seeds Climax cv. in different germinative treatments. Ponta Grossa, PR, 2012. *By the Duncan test $\mathrm{P}<0.05$, means followed by the same letter do not differ among themselves. 
mancy in seeds of Vaccinium spp. are often manifested by the low and irregular germination, as observed in $V$. angustifolium, V. ashei, V. canadense, V. corymbosum, V. macrocarpon and V. oxycoccus [23]. In wild oat dormant seeds the use of $\mathrm{KOH}$ promoted significantly improvement on the germination [19]. Similarly seeds of Vaccinium angustifolium Ait. had maximum germination (approximately 80\%) when treated with $5.3 \mathrm{M}$ of $\mathrm{KOH}$ for 5 minutes [24]; results that were not seen in the tested cultivars of this study, showing that within the same genus, species have different behavior regarding $\mathrm{KOH}$ usage.

The usage of paper filter as a substrate has been observed in the seeds germination of Vaccinium membranaceum [25], Vaccinium arctostaphylos L. [26] and Vaccinium parvifolium Smith [7]. On the other hand, the culture medium MS with 1/3,1/8 and 1/16 of the original salt concentration has been tested as a substrate [13] in the seeds germination of Vaccinium meridionale. Promoting germination percentages of 48, 63, 63.5\% respectively. In the present experiment both substrates, SP and MS/2, promoted seeds germination of the Vaccinium ashei Reade for both tested cultivars.

Many temperature schemes can affect the germination of Vaccinium sp [7], fact that can be observed over the different temperatures used for germination of seeds of this genus. In order to simulate Canadian typical spring conditions, seeds of Vaccinium angustifolium Ait. were germinated at $10^{\circ} \mathrm{C}$ [24]. On the other hand, when working with Vaccinium myrtillus L. and Vaccinium vitis-idaea, obtained germination of $62 \%-100 \%$ in presence of light and alternate temperatures of $20: 10^{\circ} \mathrm{C}$ [27]. In the present study both constant temperatures of $10^{\circ} \mathrm{C}$ $\pm 2^{\circ} \mathrm{C}$ (BOD) and $25^{\circ} \mathrm{C} \pm 2^{\circ} \mathrm{C}$ (SC) enabled the germination of Vaccinium ashei Reade seeds, although Climax cultivar, when variables were maintained constant, using or not $\mathrm{KOH}$ and substrate, at $25^{\circ} \mathrm{C}$, showed germination percentage statistically superior than the one at $10^{\circ} \mathrm{C}$.

Experiment 2-Levels of seeds viability of Vaccinium ashei Reade cultivars Briteblue and Climax through thetetrazolium test

In order to obtain satisfactory results in the tetrazolium test, is required that the $2,3,5$, triphenil tetrazolium bromide solution is absorbed by the seeds. Thus, some species need preparation steps, such as puncture, cut and/or removal of the seed coat [21]. The puncture of the seed coat with a needle was essential so that the tetrazolium solution was able to act inside the seed, demonstrating impermeability by the tested cultivars. The class levels established in the tetrazolium test for the Briteblue and Climax cvs. seeds are represented in percentage staining red-orange of the embryo (Figure 3 and Figure 4). Embryos Vaccinium meridionale Swartz, treated with tetrazolium solution at $1 \%$, showed staining from light pink to dark pink, with shades of Orange [8]. Embryos with less than $50 \%$ of staining red-orange were considered not viable. The number of classes depends on the seed staining, morphological characteristics of the specie, and on the applied treatments, and for different species, distinct levels of classes can be proposed [28].

Accordingly with the levels of proposed classes, to Briteblue cv., were considered viable the seeds that presented $50 \%, 75 \%$ and $100 \%$ of staining red-orange of the embryo (Figures $3(d)$-(f)), which represent respectively
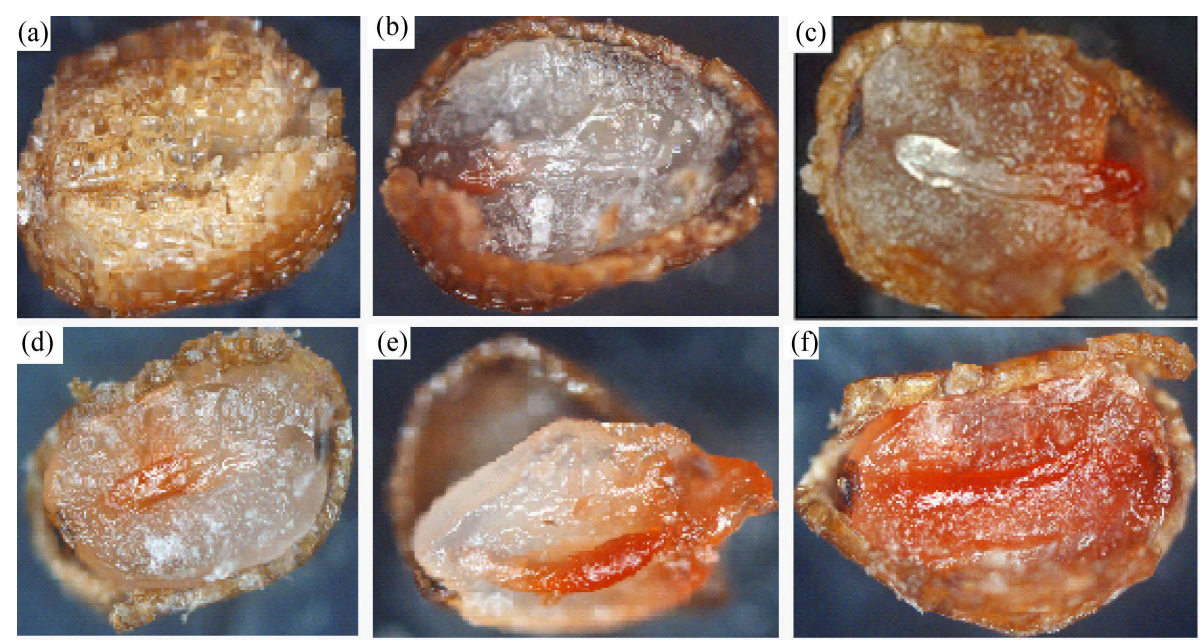

Figure 3. Embryo staining (a) dead (b) $0 \%$ (c) $25 \%$ (d) $50 \%$ (e) $75 \%$ and (f) $100 \%$ of blueberry seeds of Briteblue cv. treated with 2,3,5 tripenyl tetrazolium bromide solution. Ponta Grossa, PR, 2013. 
13\%, $7 \%$ and $9 \%$ of the evaluated seeds (Figure 5(a)). Seeds that showed red-orange embryo staining of approximately $25 \%$ (Figure 3(c)) corresponded to $20 \%$ of the sample and were not considered viable, as well as those that were not stained (dead or 0\% of red-orange staining-(Figure 3(a) and Figure 3(b)), which represented 51\% of the sample (Figure 3(a)), and from this percentage dead seeds correspond to $46 \%$.

The same viability standards used to analyze the Briteblue cv. results, which were also used for Climax cv., were considered viable for the seeds that presented $50 \%, 75 \%$ and $100 \%$ of embryo staining red-orange (Figures 4(d)-(f)) and that represented respectively $8 \%, 13.5 \%$ and $28.5 \%$ of the sample (Figure 4(b)). Seeds that showed red-orange embryo staining of approximately 25\% (Figure 4(c)) corresponded to $19 \%$ of the sample and were not considered viable. Those that were not stained ( $0 \%$ of red-orange staining or dead) represented $31 \%$ of the sample (Figure 5(b)).

Adding the percentage of the seeds that had the embryo stained red-orange over $50 \%$ in the tetrazolium test, $29 \%$ of the Briteblue cv. seeds and $50 \%$ of the Climax cv. seeds were considered viable. Vaccinium meridionale Swartz submitted to the tetrazolium test showed $84.2 \%$ of viability, and from those, $63 \%$ germinated and $21.2 \%$ did not germinate (remained dormant) [8]. The low percentage of germination of seeds can be related to elevated number of unviable seeds in the tetrazolium test, or viables that remained in latent state.

\section{Conclusions}

Briteblue and Climax cvs. of blueberry seeds, which were pre-treated with $5 \mathrm{M}$ of $\mathrm{KOH}$ for 5 minutes and germi-
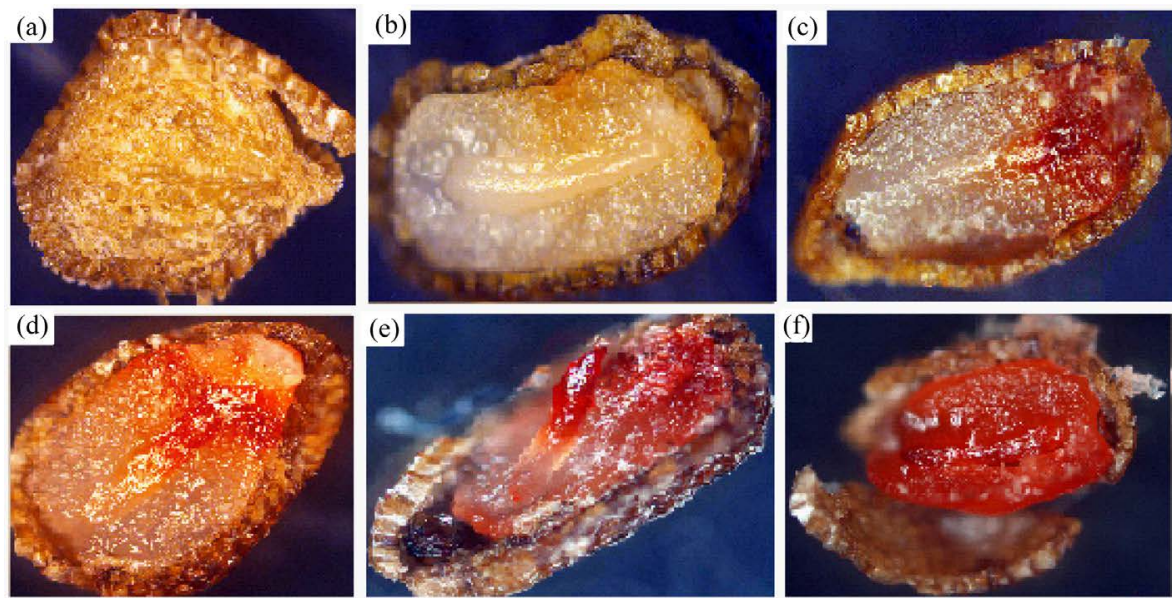

Figure 4. Embryo staining (a) dead (b) $0 \%$ (c) $25 \%$ (d) $50 \%$ (e) $75 \%$ and (f) $100 \%$ of blueberry seeds of Climax cv. treated with 2,3,5 tripenyl tetrazolium bromide solution. Ponta Grossa, PR, 2013.

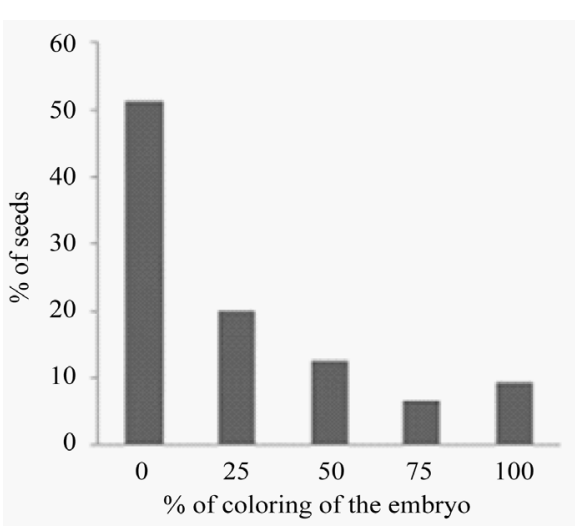

(a)

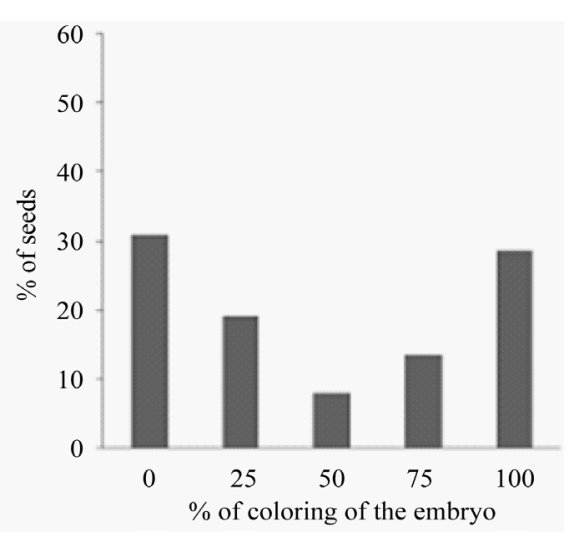

(b)

Figure 5. Percentage of staining of the blueberry seeds embryo (a) Briteblue cv. and (b) Climax cv., treated with 2,3,5 triphenyl tetrazolium bromide. 
nated on the same substrate at the same temperature, had low germination percentage in relation with the nontreated seeds.

Blueberry seeds of both tested cultivars had their germinative behavior altered when the variables temperature $\left(10^{\circ} \mathrm{C}\right.$ and $\left.25^{\circ} \mathrm{C}\right)$ and substrate (SP and $\left.\mathrm{MS} / 2\right)$ were combined.

Vaccinium ashei Reade blueberry seeds treated with combination of the variables: exposure or not to $\mathrm{KOH}$, substrates (SP and $\mathrm{MS} / 2)$ and temperature $\left(10^{\circ} \mathrm{C}\right.$ and $25^{\circ} \mathrm{C}$ ) required up to 46 days to emit the first normal seedling and showed slow germination, and after 6 months of beginning the germination test, germination percentage dose did not exceed $40 \%$.

The tetrazolium test, based on the staining of the fabrics, allows the establishment of different levels of viability, which is valuable for blueberry seeds.

\section{Acknowledgements}

Research support by CAPES, ARAUCÁRIA FOUNDATION, and UEPG.

\section{References}

[1] Poll, H., Kist, B.B., Santos, C.E., Reetz, E.R., Carvalho, C. and Silveira, D.N. (2013) De bom tamanho: segmento das pequenas frutas constitui boa alternativa de renda para os produtores brasileiros e já cria oportunidades valiosas para o país. In: Gazeta Santa Cruz, Ed., Anuário Brasileiro da Fruticultura, Santa Cruz do Sul, 136 p. http://www.grupogaz.com.br/tratadas/eo_edicao/4/2013/04/20130401_e36fb3c90/pdf/3853_fruticultura_2013.pdf

[2] Fachinello, J.C. (2008) Mirtilo. Revista Brasileira de Fruticultura, 30, 285-576. http://dx.doi.org/10.1590/S0100-29452008000200001

[3] de Oliveira Fischer, D.L., Fachinello, J.C., de Brum Piana, C.F., Bianchi, V.J. and Machado, N.P. ( 2014) Seleção de genótipos de mirtileiro obtidos a partir de polinização aberta. Revista Brasileira de Fruticultura, 36, 221-231. http://dx.doi.org/10.1590/0100-2945-299/13

[4] Carvalho, J.A., Pinho, É.V.R.V., Oliveira, J.A., Guimarães, R.M. and Bonome, L.T. (2002) Testes rápidos para avaliação da qualidade fisiológica de sementes de Citromelo swingle. Revista Brasileira de Sementes (Online), 24, 263-270. http://www.scielo.br/pdf/rbs/v24n1/v24n1a37.pdf

[5] Amaro, M.S., Medeiros Filho, S., Guimarães, R.M. and Teófilo, E.M. (2006) Influência da temperatura e regime de luz na germinação de sementes de janaguba (Himatanthus drasticus (Mart.) Plumel.). Ciência e Agrotecnologia, 30, 450457. http://dx.doi.org/10.1590/S1413-70542006000300010 http://www.scielo.br/pdf/cagro/v30n3/v30n3a10.pdf

[6] Biondi, D. and Leal, L. (2008) Tratamentos pré-germinativos em sementes de Mimosa strobiliflora Burkart. Scientia Agraria, 9, 245-248. http://dx.doi.org/10.5380/rsa.v9i2.11013

http://dialnet.unirioja.es/servlet/articulo?codigo $=2902758$

[7] Lopez, O.A., Barney, D.L., Shafii, B. and Price, W.J. (2008) Modeling the Effects of Temperature and Gibberellic Acid Concentration on Red Huckleberry Seed Germination. Hortscience, 43, 223-228. http://dialnet.unirioja.es/servlet/articulo?codigo=2902758

[8] Hernández, M.I.P., Lobo, M.A., Medina, C.I.C., Cartagena, J.R.V. and Delgado, O.A.P. (2009) Comportamiento de la germinación y categorización de la latencia em semillas de mortiño (Vaccinium meridionale Swartz). Agronomía Colombiana, 27, 15-23. http://www.scielo.org.co/pdf/agc/v27n1/v27n1a03.pdf

[9] Walck, J.L., Hidayati, S.N., Dixon, K.W., Thompson, K. and Poschlod, P. (2011) Climate Change and Plant Regeneration from Seed. Global Change Biology, 17, 2145-2161. http://dx.doi.org/10.1111/j.1365-2486.2010.02368.x http://www.readcube.com/articles/10.1111\%2Fj.1365-2486.2010.02368.x?r3_referer=wol\&tracking_action=preview_c lick\&show_checkout=1\&purchase_referrer=onlinelibrary.wiley.com\&purchase_site_license=LICENSE_DENIED

[10] Guedes, R.S., Alves, E.U., Gonçalves, E.P., Braga Júnior, J.M., Viana, J.S. and Colares, P.N.Q. (2010) Substratos e temperaturas para testes de germinação e vigor de sementes de Amburana cearensis (Allemão) A.C. Smith. Revista Árvore, 34, 57-64. http://dx.doi.org/10.1590/S0100-67622010000100007

[11] Di Salvatore, M., Carafa, A.M. and Carratù, G. (2008) Assessment of Heavy Metals Phytotoxicity Using Seed Germination and Root Elongation Tests: A Comparison of Two Growth Substrates. Chemosphere, 73, 1461-1464. http://www.sciencedirect.com/science/article/pii/S0045653508009831 http://dx.doi.org/10.1016/j.chemosphere.2008.07.061

[12] Murashige, T. and Skoog, F. (1962) A Revised Medium for a Rapid Growth and Bioassays with Tobacco Tissues Cultures. Physiologia Plantarum, 15, 473-479. http://onlinelibrary.wiley.com/doi/10.1111/j.1399-3054.1962.tb08052.x/abstract 
[13] Castro, C., Olarte, Y., Rache, L. and Pacheco, J. (2012) Development of a Germination Protocol for Blueberry Seeds (Vaccinium meridionale Swartz). Agronomía Colombiana, 30, 196-203. http://www.redalyc.org/articulo.oa?id=180325300005

[14] Ministério da Agricultura, Pecuária e Abastecimento (2009) Regras para análise de sementes. Secretaria de Defesa Agropecuária, Mapa/ACS, Brasília, DF, 395 p. http://www.agricultura.gov.br/arq_editor/file/2946_regras_analise_sementes.pdf

[15] Baskin, J.M. and Baskin, C.C. (2004) A Classification System for Seed Dormancy. Seed Science Research, 14, 1-16. http://dx.doi.org/10.1079/SSR2003150

[16] D’Hondt, B., Brys, R. and Hoffmann, M. (2010) The Incidence, Field Performance and Heritability of Non-Dormant Seeds in White Clover (Trifolium repens L.). Seed Science Research, 20, 169-177. http://dx.doi.org/10.1017/S0960258510000152

[17] Costa, T.G., Dias, A.H. de S., Elias, T. de. F., Breier, T.B. and Abreu, H. dos S. (2011) Lignina e a dormência em sementes de três espécies de leguminosas florestais da Mata Atlântica. Floresta e Ambiente, 18, 204-209. http://www.floram.org/files/v18n2/v18n2a11.pdf

[18] Kolattukudy, P.E. (1981) Structure, Biosynthesis, and Biodegradation of Cutin and Suberin. Annual Review of Plant Physiology, 32, 539-567. http://dx.doi.org/10.1146/annurev.pp.32.060181.002543 http://www.annualreviews.org/doi/abs/10.1146/annurev.pp.32.060181.002543

[19] Hou, J.Q. and Simpson, G.M. (1994) Effects of Immersing Dry Seeds in Alkaline Solutions on Seed Dormancy and Water Uptake in Wild Oat (Avena fatua). Canadian Journal of Plant Science, 74, 19-24. http://dx.doi.org/10.4141/cjps94-005 http://pubs.aic.ca/doi/pdf/10.4141/cjps94-005

[20] Debska, K., Krasuska, U., Budnicka, K., Bogatek, R. and Gniazdowska, A. (2013) Dormancy Removal of Apple Seeds by Cold Stratification Is Associated with Fluctuation in $\mathrm{H}_{2} \mathrm{O}_{2}$, NO Production and Protein Carbonylation Level. Journal of Plant Physiology, 170, 480-488. http://dx.doi.org/10.1016/j.jplph.2012.11.018 http://www.ncbi.nlm.nih.gov/pubmed/23347818

[21] Costa, C.J. and dos Santos, C.P. (2010) Teste de tetrazólio em sementes de leucena. Revista Brasileira de Sementes, 32, 66-72. http://dx.doi.org/10.1590/S0101-31222010000200008

[22] Köppen, W. (1948) Climatología: Com un estudio de los climas de la tierra. Fondo de Cultura Econômica, México, $479 \mathrm{p}$.

[23] Ellis, R.H., Hong, T.D. and Roberts, E.H. (1985) Chapter 36: Ericaceae: Handbook of Seed Technology for Genebanks. No. 3. In: Ellis, R.H., Hong, T.D. and Roberts, E.H., Eds., Compendium of Specific Germination Information and Test Recommendations, Vol. 2, International Board for Plant Genetic Resources, Rome, 456 p. http://www.bioversityinternational.org/fileadmin/user_upload/online_library/publications/pdfs/52.pdf

[24] Gao, Y.P., Zheng, G.H. and Lawrence, V.G. (1988) Potassium Hydroxide Improves Seed Germination and Emergence in Five Native Plant Species. Hortscience, 33, 274-276. http://hortsci.ashspublications.org/content/33/2/274.full.pdf

[25] Barney, D.L., Shafii, B. and Price, W.J. (2001) Cold Stratification Delays Germination of Black Huckleberry Seeds. Hortscience, 36, 813. http://hortsci.ashspublications.org/content/36/4/813.full.pdf

[26] Shahram, S. (2007) Seed Dormancy and Germination of Vaccinium arctostaphylos L. International Journal of Botany, 3, 307-311. http://dx.doi.org/10.3923/ijb.2007.307.311 http://www.researchgate.net/publication/26609984

[27] Baskin, C.C., Milberg, P., Andersson, L. and Baskin, J.M. (2000) Germination Studies of Three Dwarf Shrubs (Vaccinium, Ericaceae) of Northern Hemisphere Coniferous Forests. Canadian Journal of Botany, 78, 1552-1560. http://dx.doi.org/10.1139/b00-129 http://www.nrcresearchpress.com/doi/abs/10.1139/b00-129\#.VmnBSHarTIU

[28] Sarmento, M.B., da Silva, A.C.S., Villela, F.A., dos Santos, K.L. and de Mattos, L.C.P. (2013) Teste de tetrazólio para avaliação da qualidade fisiológica em sementes de goiabeira-serrana (Acca sellowiana O. Berg Burret). Revista Brasileira de Fruticultura, 35, 270-276. http://dx.doi.org/10.1590/S0100-29452013000100031 